\title{
A sublime loucura de Nietzsche $^{*}$
}

\author{
Paul de Mantain**
}

Resumo: Analisando Ecce homo como uma obra que Nietzsche teria escrito "à beira da loucura definitiva", algo que transpareceria também em suas cartas finais, o autor julga que o filósofo alemão sobrestimava demais a si próprio, possuindo traços megalomaníacos que o conduziram a julgar-se como o "reformador do mundo" e o "guia espiritual da humanidade". Pretensões estas que, embora sob a influência do delírio, em nada desvaneceriam o gênio de Nietzsche.

Palavras-chave: Nietzsche - Ecce homo - loucura - gênio sublime.

"O sublime está a um passo do ridículo", já se disse certa vez. Que é o sublime? Que é o ridículo? O que é sublime para uma determinada pessoa pode ser ridículo para outra. A mania de grandeza, $o$ autoelogio despertam quase sempre um piedoso sorriso. Mas isso não se dá quando se trata dum homem como Nietzsche.

Toda verdade exagerada torna-se uma mentira. Não se pode negar o gênio de Nietzsche, mas não se pode também deixar de negar que seu gênio estava abaixo do que ele próprio supunha. Há qualquer coisa de infinitamente impressionante na manifestação megalomaníaca de seus últimos delírios. Um homem do gênio de Nietzsche, com uma poderosa imaginação criadora, eis que se julga o reformador do mundo, o possuidor das grandes verdades, o anticristo, o guia espiritual da humanidade, ou, melhor ainda,

\footnotetext{
* Publicado na Revista Carioca. Rio de Janeiro, 28 fevereiro de 1942, p. 8.

** Pseudônimo de Edmundo Moniz (1911-1997), também assinado como "Paul de Maritain". Advogado, jornalista, ensaísta, teatrólogo e pensador marxista brasileiro. É autor de $O$ golpe de abril (1965) e Poemas da liberdade uma antologia poética de Dante a Brecht (1967), dentre outras obras.
} 
dos super-homens. Encontra-se à beira da loucura definitiva, da idiotice. E nestes últimos momentos que lhe restam de atividade mental, crivado de sofrimentos físicos, quase cego, numa excitação que vai ao auge, toma da pena, inspiradamente, para proclamar, com uma eloquência verbal poucas vezes atingida, que lhe cabe a glória de ter mudado o próprio curso da história. Já que principiava com ele uma nova civilização.

"Ecce homo", o Dionísio ante o crucifixo, sua autobiografia, é o último livro que compõe. Depois dele só temos algumas cartas, uma delas a Cosima Wagner com poucas palavras de desabafo que, sob certos aspectos, explica as suas desavenças com o criador das "Valquírias": "Ariana, eu te amo". Escreve também a Burckardt, a Overbeck, a Brandes, e suas missivas os deixam imensamente apreensivos. Não se esquece da mãe e confessa numa última carta: "O teu velho rebento é agora um animal enormemente célebre, embora não o seja, é claro, na Alemanha, cujos habitantes são demasiados estúpidos e vulgares ante a altura de meu espírito". E acrescenta: "Não há nome atualmente que se pronuncie com maior admiração e veneração do que o meu." Então se julga elevado a uma altitude inatingível, vivendo entre os sóis, numa atmosfera voluptuosa e cegadora de luzes intensas e deliciosas harmonias.

Todavia, é justo que se diga: o delírio de Nietzsche não o desvanece. Não o leva ao ridículo. É um delírio que dá uma sublimidade maior ao seu gênio. Tem qualquer coisa de forças portentosas que se desencadeiam, que perdem o equilíbrio, o ritmo, a harmonia, e atingem um estado caótico cheio de sombras e de resplendores.

Os títulos dos capítulos de "Ecce homo" são os seguintes: "Por que sou tão sábio", "Por que sou tão sagaz", "Por que escrevo bons livros", "Por que sou uma fatalidade". No inicio do último capitulo exclama:

"Conheço o meu destino. Sei que algum dia o meu nome se aliará, em recordação a algo de terrível, a uma crise como nunca 
ocorreu, à tremenda colisão de consciência, a uma sentença definitiva, pronunciada contra tudo aquilo que se acreditava, exigia e santificava até então. Eu não sou um homem: sou uma dinamite. $\mathrm{E}$, não obstante tudo isso, não tenho rompantes de fundador de religiões: as religiões são coisas de gentalha: eu sinto a necessidade de lavar as mãos depois de ter tocado as de um homem religioso... Não quero "crentes"; acredito que sou demasiado mau para crer em mim mesmo; eu nunca falo às massas... Tenho grande medo de ser, algum dia, santificado; desse modo, compreenderão porque eu publico antes este livro: deve ele evitar que se abuse de meu nome... Não quero ser um santo: prefiro ser um palhaço... Talvez seja eu um palhaço... Todavia, ou talvez não todavia - porque até agora não há nada tão mentiroso quanto os santos - eu falo a verdade. A minha verdade é espantosa, porque agora a mentira se denominou verdade. "Transmutação de todos os valores": eis a minha fórmula para um ato de suprema determinação de si mesmo na humanidade, ato que em mim se tornou carne e gênio. $\mathrm{O}$ meu destino exige que eu seja o primeiro homem honesto, que eu me sinta em oposição às mentiras de vários milênios...".

"Sozinho, fui eu o descobridor da verdade porque fui o primeiro a sentir como tal a mentira... O meu gênio está nas minhas narinas. Polemizo como nunca se polemizou e, entretanto sou o contrário dum espírito negativo".

"Eu sou mensageiro feliz: nunca houve outro; conheço destinos tão elevados que até agora nem sequer foi possível concebê-los; somente com meu advento se reanimam as minhas esperanças. Por isso, sou também necessariamente o homem fatal; porque se a verdade entra em luta com a mentira milenária, haverá convulsões, terremotos, deslocações de montanhas e de vales, coisas que nunca se imaginaram nem mesmo em sonhos. Então, o conceito de política se absorverá todo em uma luta de espíritos, e todas as formações potenciais da antiga sociedade irão para os ares, porque todas se assentam na mentira: haverá guerras como 
Mantain, P.

nunca houve na terra. Somente depois de mim começará no mundo a "grande política" "

É pena que o "Zaratustra" em carne e osso sobrestimasse o seu próprio destino. Mas indiscutivelmente temos no "Ecce Homo" o epílogo maravilhoso duma obra gigantesca que há de viver para sempre.

\begin{abstract}
Through the analysis of Ecce homo, a work written by Nietzsche "on the edge of absolute madness," which is visible as well in his final letters, the author concludes that the German philosopher overestimated himself, presenting megalomaniac features that led him into thinking of himself as the "world reformer" and "spiritual guide to humanity." These self-attributions, even if delusional, did not slender in any way Nietzsche's genius.
\end{abstract}

Keyword: Nietzsche - Ecce homo - madness - genius - sublime. 